\title{
PENGARUH PENERAPAN MANAJEMEN STRATEGIS DAN KOMPETENSI KEPALA SEKOLAH TERHADAP PENCAPAIAN STANDAR PENGELOLAAN PENDIDIKAN DI SMA NEGERI 19 MAKASSAR
}

\author{
MUH. YUSUF DJ, ST. SYAMSUDDUHA, MUH. RAPI \\ Pascasarjana UIN Alauddin Makassar \\ Email: muhyusuf546@gmail.com, st.syamsudduha@uin-alauddin.ac.id, mrapi@uin- \\ alauddin.ac.id
}

\begin{abstract}
:
The objectives of this study are: First, describe the application of strategic management, the competence of principals, and describe the application of educational management standards; the second examines the influence of strategic management and school principals' competencies on achieving educational management standards in Makassar 19 Public High School. This type of research is survey research. The total population is 579, and 121 samples are taken. Data collection uses questionnaire and documentation techniques. The data analysis uses descriptive statistics and inferential statistics. The results of this study indicate that, strategic management and competency of school principals jointly have a positive and significant effect on the achievement of education management standards in SMA 19 Makassar with a regression equation $Y=50,450+0.467 \times 1+0.216 \times 2$ and the coefficient of determination of 0.209 so that the achievement of educational management standards $20.9 \%$ is determined by strategic management together with the competency of principals and $79.1 \%$ is determined by other factors not included in this research area.
\end{abstract}

Keywords: Strategic Management, Principal Competence, Education Management Standards.

\section{PENDAHULUAN}

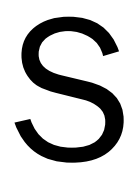

tandar pengelolaan pendidikan pada jenjang satuan pendidikan merupakan suatu capaian minimal yang harus terpenuhi di setiap lembaga pendidikan agar menghasilkan peserta didik yang berkualitas. Pengelolaan pendidikan merupakan suatu kriteria kerja yang mengarah pada proses perencanaan, pelaksaan, dan sampai pada tahap evaluasi pendidikan pada tingkat satuan pendidikan.

Permasalahan tentang pengelolaan pendidikan sudah merambah ke berbagai aspek di setiap daerah, tak terkecuali di daerah Manggala Kota Makassar, lebih tepatnya berada di SMA Negeri 19 Makassar berdasarkan survey yang telah dilakukan. Hal ini dapat dibuktikan dengan ketidaktersediaan sarana dan prasarana yang memadai yang yang dapat dilihat dari ruang belajar yang masih kurang, ketersediaan media pembelajaran yang tidak memadai, alat laboratorium praktek yang kurang memadai dan berbagai fasilitas lainnya yang mengindikasikan ketidaktersediaan sarana dan prasarana yang memadai di sekolah tersebut. 
Masalah prestasi, para peserta didik yang ada di SMA Negeri 19 Makassar juga masih kalah saing dalam beberapa event atau kejuaraan yang diselenggarakan di daerah setempat. Hal tersebut mengindikasikan bahwa pengelolaan pendidikan yang dalam hal ini input, proses dan output di SMA Negeri 19 Makassar masih jauh dari kata bermutu.

Permasalahan yang tidak kalah seriusnya juga terletak pada pimpinan (kepala sekolah) di SMA Negeri 19 Makassar. Permasalahan dalam hal ini adalah ketidakmampuan seorang kepala sekolah untuk mempengaruhi bawahannya dalam mengendalikan dan menjalankan tugas dan fungsinya.Bukti ketidakmampuan kepala sekolah adalah terjadinya ketidakharmonisan dalam bekerja antara kepala sekolah dan jajarannnya, hubungan yang tidak sejalan pendapat sehingga menimbulkan gejala tersebut. Hasil observasi awal yang dilakukan membuktikan bahwa kepala sekolah di SMA Negeri 19 Makassar tidak mampu menjadi leader untuk semua jajarannya. Hasil wawancara dengan salah satu warga sekolah dikatakan bahwa kepala sekolah tidak memiliki kompetensi manajerial yang baik dan juga jiwa kepemimpinan yang memadai. Hal ini dapat dilihat pada cara kepala sekolah mengelola sumber daya sekolah dan cara kepala sekolah dalam memutuskan suatu persoalan yang hampir pasti sering menimbulkan perdebatan dan ketidaksetujuan dari bawahan. Kondisi di atas sangat mempengaruhi lingkungan kerja yang berdampak pada hasil kerja yang tidak optimal bahkan sampai padaterkendalanya suatu pekerjaan, sehingga, mutu pendidikan di SMA Negeri 19 Makassar belum tercapai dengan baik.

\section{TINJAUAN TEORETIS}

\section{Manajemen Strategis}

Istilah manajemen pada umumnya mengandung 3 unsur pengertian yaitu, manajemen sebagai suatu proses, kedua manajemen sebagai suatu kolektivitas orang-orang yang melakukan aktivitas, dan ketiga, manajemen sebagiseuatu seni dan disiplin ilmu (Manuling:2006). Adapun menurut Pearce dan Robinson (2013), manajemen strategi dapat diartikan sebagai kumpulan tindakan yang menghasilkan perumusan (formulasi) dan berupa pelaksanaan (implementasi) rencana yang dirancang untuk mencapai sasaran organisasi. Sementara menurut Hunger dan Wheelen (2003), manajemen strategi adalah serangkaian keputusan dan tindakan dari manajerial yang menentukan kinerja organisasi dalam jangka panjang. Manajemen strategi meliputi pengamatan lingkungan internal dan eksternal, perumusana strategi, implementasi strategi dan evaluasi strategi serta pengendalian dan tahap evaluasi strategi. Sehingga dengan demikin manajemen strategi juga menekankan pada pengamatan dan evaluasi peluang dan acaman lingkungan internal dan eksternal dengan meilihat kelemahan kekuatan suatu organisasi.

Manajemen strategis memiliki beberapa tahap dalam pelaksanaannya. Hunger dan Wheelen (2003), mengutarakan bahwa manajemen strategis memiliki tiga tahap, yaitu tahap perumusan strategi, implementasi strategi dan tahap evaluasi dan 
pengembangan stretagi. Berdasarkan tahap-tahap tersebut, sekiranya akan memberikan gambaran positif bahwa manajemen strategis dapat menjadi suatu alat dalam menignkatkan mutu pendidikan.

\section{Kompetensi kepala sekolah}

Kepemimpinan berasal dari kata "pimpin" yang memuat dua hal pokok yaitu, pemimpin sebagai subjek dan dipimpin sebagai objek. Kata pimpin mengandung makna mengarahkan, membina atau mengatur, membina, menuntun dan juga menunjukan tanggung jawab yang lebih baik secara fisik maupun spiritual terhadap keberhasilan aktivitas kerja yang dipimpinnya. Sedangkan dalam Suryana dan Suryadi (2009) mendefinisikan bahwa kepemimpinan adalah rangkaian kegiatan penataan berupa kemampuan mempengaruhi perilaku orang lain dalam situasi tertentu agar bersedia bekerjasama untuk mencapai tujuan yang telah ditetapkan.

Sementara itu, menurut Robbins dalam Machali dan Hidayat (2016), kepemimpinan adalah kemampuan untuk mempengaruhi sekelompok anggota agar bekerja mencapai tujuan dan sasaran yang telah ditetapkan. Pengertian tersebut menunjukan bahwa seorang pemimpin adalah anggota kelompok yang berposisi khusus dan memiliki kemampuan untuk mempengaruhi anggotanya agar bekerja dengan baik dan tepat untuk mencapai tujuan dan sasaran yang telah ditetapkan. Kepemimpinan dalam konteks lembaga pendidikan, peran kepemimpinan diambil alih dan dilaksanakan oleh kepala sekolah. Pengertian kepala sekolah menurut Wahdjosumidjo (2004) adalah kepala sekolah sebagai seorang tenaga fungsional guru yang diberi tugas untuk memimpin sekolah tempat diselenggarakan proses belajar mengajar atau tempat tejadinya interaksi antara guru yang memberipelajaran dan peserta didik yang menerima pelajaran. Sementara Daryanto (2011) mengatakan bahwa kepala sekolah adalah guru yang mempunyai kemampuan untuk memimpin segala sumber daya yang ada pada suatu sekolah sehingga dapat didayagunakan, sehingga kepala sekolah adalah seorang pemimpian (leader) yang memiliki peran khusus untuk mengelola lembaga pendidikan atau sekolah.

Keberhasilan kepala sekolah dalam menjalankan tugasnya banyak ditentukan oleh kompetensi kepala sekolah dalam lembaga pendidikan. Oleh sebab itu, kepala sekolah diharuskan memiliki kemampuan dalam mengelola setiap komponen yang ada dalam sekolah. Selain itu, kepala sekolah juga harus mampu mamiliki pemahaman terkait ilmu manajemen dan kepemimpinan serta juga harus memahami tugas dan tanggung jawab yang diemban oleh seluruh kepala sekolah. Kepala sekolah sebagai salah satu bagian dari komponen organisasi atau sekolah, maka kepala sekolah harus dapat memberikan pelayanan yang prima untuk kemajuan sekolah dengan kompetensi yang dimiliki serta harus dikembangkan oleh kepala sekolah sesuai dengan kebutuhan dan tuntutan lingkungan sekolah.

Adapun kompetensi kepala sekolah yang tertuang dalam standar kompetensi kepala sekolah diantaranya, Peraturan Menteri Pendidikan Pendidikan Nasional Nomor 13 Tahun 2007 tentang Standar Kepala Sekolah telah menetapkan standar 
kompetensi yang harus dimiliki oleh kepala sekolah yaitu, kompetensi kepribadian, kompetensi manajerial, kompetensi supervisi, kompetensi supervisi, dan kompetensi sosial. Pemimpin di suatu lembaga pendidikan dalam menjalankan kepemimpinannya harus memiliki minimal 5 kompetensi yang menjadi keharusan dalam diri seorang pemimpin lembaga pendidikan atau seorang kepala sekolah.

\section{Standar Pengelolaan Pendidikan}

Mengingat pendidikan di Indonesia membutuhkan standar nasional pendidikan yang dapat menyesuaikan diri dengan kehidupan masyarakat, oleh karena itu disusunlah standar nasional pendidikan dengan berbagai landasan dan perubahan sesuai dengan tuntutan kehidupan masyarakat. Standarisasi pendidikan nasional yang dimaksud adalah standar pendidikan yang tertuang dalam Peraturan Pemerintah Nomor 19 Tahun 2005, kemudian mengalami perubahan pertama menjadi PP Nomor 13 Tahun 2013 dan kemudian kembali perubahan pada perubahan kedua menjadi PP Nomor 13 Tahun 2015 tentang Standar Nasional Pendiidkan meliputi; standar isi, standar proses, standar pendidik dan tenaga kependidikan, standar sarana dan prasarana, standar pengelolaan, standar pembiayaan dan standar penilaian pendidikan. Peraturan tersebut saat ini telah disesuakan dengan dinamika perkembangan masyarakat guna mencapai tujuan pendidikan nasional.

Standar pengelolaan pendidikan sebagaimana yang tertuang dalam PP No 13 Tahun 2015 dikatakan bahwa standar pengelolaan merupakan standar pendidikan nasional yang berkaitan dengan perencanaan, pelaksanaan, dan pengawasan kegiatan pendidikan pada tingkat satuan pendidikan, kabupaten/kota, atau provinsi agar tercapai suatu hasil yang efektif dan efisien dalam lembaga pendidikan (Mulyasa, 2013).

Senada dengan itu, juga dijelaskan dalam Peraturan Pemerintah Nomor 13 Tahun 2015 bahwa standar pengelolaan pendidikan mencakup lingkup perencanaan program, pelaksanaan, pengawasan dan evaluasi. Setiap pendidikan wajib memenuhi standar pengelolaan pendidikan yang berlaku secara nasional. Oleh sebab itu, dengan melakukan standarisasi pengelolaan pendidikan ini diharapkan dapat menjadi spirit dan power untuk bersaing dengan sekolah-sekolah lainnya, sehingga dalam proses pengelolaan pendidikan, pemerintah memeberikan otonomi atau kebebasan sekolah untuk berekspresi dalam pengembangakan dan peningkatkan pengelolaan sekolah yang mengarah pada peningkatan mutu pendidikan pada lembaga pendidikan. Adapun komponen-komponen dalam standar pengelolaan pendidikan yang tertuang dalam peraturan tersebut adalah; perencanaan program, pelaksanaan program, evaluasi, SIM dan kepemimpinan. Kelima komponen tersebut saling berhubungan dalam mencapai suatu standar pengelolaan yang telah ditetapkan bersama. 


\section{METODE PENELITIAN}

Jenis penelitian ini menurut metodenya adalah penelitian survei (survey research), yaitu jenis penelitian yang mempelajaridan menentukan sampel yang diambil dari suatu populasi tertentu. Menurut Sugiyono (2014) penelitian survei adalah metode penelitian kuantitatif yang digunakan untuk mendapatkan data yang terjadi pada masa lampau atau saat ini tentang keyakinan, pendapat, karakteristik, perilaku, hubungan variabel dan untukmenguji beberapa hipotesis tentang variabel berdasarkan sampel yang diambil dari populasi tertentu, teknik pengumpulan data dengan kuesioner dan hasil penelitian cenderung untuk digeneralisasikan.

Penelitian ini dilangsungkan di SMA Negeri 19 Makassar Kecamatan Manggala Kota Makassar. Menurut Tiro (2014), populasi dalam penelitian adalah seluruh stakeholders yang ada di sekolah tersebut. Sementara itu, sampel adalah sebagian dari populasi yang terpilih dan mewakili populasi tersebut (Muri, 2014). Adapun sampel dalam penelitian ini sejumah 121 orang yang diambil dari seluruh populasi dari total 579 populasi. Sampel yang diambil 15\% jualah siswa yang populasinya sebesar 539 sebanyak 81 siswa, dan seluruh pendidik dan tenaga pendidik yang totalnya sebanyasebanyak 40 orang. Jadi secara keseluruhan total populasi 579 , kemudian diambil sampel sebanyak 121, yang kemudian dijadikan sebagai responden dalam proses pengumpulan data.

Instrumen yang digunakan dalam pengumpulan data berupa daftar angket dan check list. Pertanyaan angket tertutup tersebut menggunakan skala Likert 1-5 dengan menggunakan pertanyaan berskala (scaling questions). Adapun jawaban setiap item instrumen yang menggunakan skala Likert ini memiliki gradasi mulai dari sangat positif hingga sangat negatif. Sementara Analisis dalam penelitian ini menggunakan analisis statistik deskriptif dan analisis statistik inferensial.

\section{HASIL PENELITIAN DAN PEMBAHASAN}

\section{Deskripsi Manajemen Strategis, Kepemimpinan kepala Sekolah dan Standar Pengelolaan Pendidikan di SMA Negeri 19 Makassar}

Manajemen strategis berada pada kategori baik, dengan persentase sebesar 77,21\%. Realitas manajemen strategis pada SMA Negeri 19 Makassar adalah $65,63 / 85=0,7721$ atau $77,21 \%$ dari kriteria yang diharapkan (100\%). Adapun Kompetensi kepala sekolah berada pada kategori cukup, dengan persentase sebesar 65,53\%. Realitas kompetensi kepala sekolah pada SMA Negeri 19 Makassar adalah 39,32 / $60=0,6553$ atau 65,53\% dari kriteria yang diharapkan (100\%). Sementara itu, Pencapaian standar pengelolaan pendidikan berada pada kategori baik, dengan persentase sebesar $81,45 \%$. Realitas pencapaian standar pengelolaan pendidikan pada SMA Negeri 19 Makassar adalah 89,60/110 = 0,8145 atau $81,45 \%$ dari kriteria yang diharapkan (100\%). 
Besarnya pengaruh manajemen strategis dan kompetensi kepala sekolah secara bersama-sama terhadap pencapaian standar pengelolaan pendidikan dapat dilihat pada hasil uji determinasi melalui SPSS versi 21 pada tabel 1.

Tabel 1. Output Pengujian Determinasi Pencapaian Standar Pengelolaan Pendidikan Atas Manajemen Strategis dan Kompetensi kepala sekolah secara Bersama-sama

\begin{tabular}{ccccc}
\hline Model & $\mathrm{R}$ & $R$ Square & Adjusted $R$ Square & $\begin{array}{c}\text { Std. Error of the } \\
\text { Estimate }\end{array}$ \\
\hline 1 & $.457^{\mathrm{a}}$ & .209 & .196 & 5.985 \\
\hline
\end{tabular}

* Predictors: (Constant), Kompetensi kepala sekolah, Manajemen Strategis

Sumber : Data diolah, 2019

Berdasarkan pada Tabel 1 ditunjukkan bahwa nilai koefisien determinasi ( $R$ Square) sebesar 0,209. Dengan demikian, besarnya pengaruh manajemen strategis dan kompetensi kepala sekolah secara bersama-sama terhadap pencapaian standar pengelolaan pendidikan di SMA Negeri 19 Makassar adalah 20,9\% dan 79,1\% ditentukan oleh faktor lain.

\section{Pengaruh Manajemen Strategis terhadap Pencapaian Standar Pengelolaan Pendidikan di SMA 19 Makassar}

Hasil analisis regresi linear sederhana diperoleh persamaan regresi

$$
Y=53,370+0,552 X
$$

Hal tersebut mengindikasikan bahwa jika manajemen strategis $\left(X_{1}\right)$ naik satu satuan, pencapaian standar pengelolaan pendidikan (Y) dapat diprediksikan meningkat sebesar 0,552 (55,2\%) pada konstanta 53,370. Pengaruh manajemen strategis terhadap pencapaian standar pengelolaan pendidikan berdasarkan tabel Anova menunjukkan bahwa nilai F sebesar 20,268 dengan nilai Sig. 0,000. Nilai Sig. 0,000 tersebut lebih kecil dari 0,05 yang mengindikasikan bahwa $\mathrm{H}_{0}$ ditolak dan $\mathrm{H}_{1}$ diterima. Hal ini menunjukkan adanya pengaruh positif dan signifikan manajemen strategis terhadap pencapaian standar pengelolaan pendidikan. Besarnya pengaruh manajemen strategis terhadap pencapaian standar pengelolaan pendidikan di SMA 19 Negeri Makassar berdasarkan uji determinasi adalah 14,6\% dan 85,4\% ditentukan oleh faktor lain.

Manajemen strategis yang diterapkan di SMA Negeri 19 Makassar berdasarkan analisis deskriptif menunjukkan bahwa sudah terlaksana dengan baik. Hal tersebut sesuai dengan konsep yang dikemukakan oleh Hunger dan Wheelen (2003), yang sama-sama menyatakan bahwa penerapan manajemen strategi dilakukan melalui beberapa tahapan, yaitu perumusan strategi, penerapan strategi, dan evaluasi dan pengembangan strategi. Ketiga tahapan tersebut berdasarkan hasil analisis yang dilakukan menunjukkan bahwa SMA Negeri 19 Makassar telah menerapkan manajemen strategis dengan baik yang diawali dengan perumusan strategi, penerapan strategi, serta melakukan evaluasi kemudian mengembangkan strategi sebelumnya agar lebih baik. 
Hasil penelitian ini mengindikasikan bahwa manajemen strategi di SMA Negeri 19 Makassar, baik dari segi perumusan strategi, penerapan strategi, maupun evaluasi strategi dapat memberikan kontribusi sebesar 14,6\% terhadap pencapaian standar pengelolaan terlepas dari faktor lain yang mempengaruhinya. Hal tersebut menandakan pentingnya manajemen strategis dalam pengelolaan pendidikan. Oleh karena itu, semakin baik manajemen strategis yang diterapkan dalam suatu sekolah, akan semakin memberikan kontribusi terhadap pencapaian standar pengelolaan pendidikan dan pada akhirnya mengarah pada peningkatan mutu pendidikan.

Pengaruh Kompetensi kepala sekolah terhadap Pencapaian Standar Pengelolaan Pendidikan di SMA Negeri 19 Makassar

Hasil analisis regresi linear sederhana diperoleh persamaan regresi

$$
Y=78,720+0,277 X
$$

Hal tersebut mengindikasikan bahwa kompetensi kepala sekolah $\left(\mathrm{X}_{2}\right)$ naik satu satuan, pencapaian standar pengelolaan pendidikan (Y) dapat diprediksikan meningkat sebesar 0,227 (22,7\%) pada konstanta 78,720. Pengaruh kompetensi kepala sekolah terhadap pencapaian standar pengelolaan pendidikan berdasarkan tabel Anova menunjukkan bahwa nilai F sebesar 14,720 dengan nilai Sig. 0,000. Nilai Sig. 0,000 tersebut lebih kecil dari 0,05 yang mengindikasikan bahwa $\mathrm{H}_{0}$ ditolak dan $\mathrm{H}_{1}$ diterima. Hal ini menunjukkan adanya pengaruh positif dan signifikan kompetensi kepala sekolah terhadap pencapaian standar pengelolaan pendidikan. Besarnya pengaruh kompetensi kepala sekolah terhadap pencapaian standar pengelolaan pendidikan di SMA Negeri 19 Makassar berdasarkan uji determinasi adalah 11\% dan $89 \%$ ditentukan oleh faktor lain. Hasil penelitian ini telah mengindikasikan bahwa kepemimpinan yang diterapkan oleh kepala sekolah SMA Negeri 19 Makassar dapat memberikan kontribusi terhadap pencapaian standar pengelolaan pendidikan. Kepala sekolah sebagai manager harus mampu melakukan pengelolaan yang baik pada sekolah yang dipimpinnya agar program atau kegiatan yang dilakukan dapat terarah demi pencapaian mutu pendidikan. Oleh karena itu, kepala sekolah harus menyadari pentingnya penerapan kepemimpinan yang efektif, terutama dalam pengelolaan lembaga pendidikan yang dipimpinnya. Penelitian ini telah membuktikan adanya pengaruh kompetensi kepala sekolah terhadap pencapaian standar pengelolaan pendidikan sebesar $11 \%$.

Hasil penelitian ini mendukung temuan Afifah (2017) yang menyimpulkan bahwa kompetensi kepala sekolah melalui penerapan fungsi kepemimpinannya dalam meningkatkan mutu pendidikan telah membawa dampak positif terhadap peningkatan mutu pendidikan. Temuan lain yang dihasilkan oleh Timor, dkk (2018). bahwa kompetensi kepala sekolah mempunyai hubungan dengan mutu sekolah dan memberikan pengaruh terhadap mutu sekolah. Hal ini mengindikasikan bahwa kepemimpinan yang diterapkan oleh kepala sekolah merupakan salah satu aspek yang turut menentukan pencapaian mutu pendidikan di sekolah. 
Fakta tersebut mengindikasikan bahwa mutu pendidikan dipengaruhi oleh kompetensi kepala sekolah. Oleh karena itu, mutu pendidikan tidak meningkat dengan sendirinya, tetapi memerlukan dukungan-dukungan dari luar, termasuk penerapan kompetensi kepala sekolah. Mutu pendidikan memiliki banyak indikator yang menentukan pendidikan dapat dikatakan bermutu, termasuk kemampuan suatu sekolah dalam mencapai standar pengelolaan pendidikan. Hasil penelitian sebelumnya yang telah dikemukakan tersebut tidak secara spesifik membuktikan kompetensi kepala sekolah berpengaruh terhadap pencapaian standar pengelolaan pendidikan, tetapi mutu pendidikan didalamnya terdapat berbagai komponen, termasuk standar pengelolaan pendidikan. Hasil penelitian ini memberikan pemahaman bahwa standar pengelolaan pendidikan sebagai bagian dari indikator pencapaian mutu pendidikan tidak terlepas dari pengaruh kemampuan kepala sekolah dalam menerapkan kepemimpinan yang efektif.

Pengaruh Kualitas Manajemen Strategis dan Kompetensi kepala sekolah secara Bersama-sama terhadap Pencapaian Standar Pengelolaan Pendidikan di SMA Negeri 19 Makassar

Hasil analisis analisis regresi linear berganda diperoleh persamaan regresi

$$
Y=50,450+0,467 X_{1}+0,216 X_{2}
$$

Pengaruh manajemen strategis secara bersama-sama dengan kompetensi kepala sekolah terhadap pencapaian standar pengelolaan pendidikan berdasarkan tabel Anova tersebut menunjukkan bahwa nilai F sebesar 15,592 dengan nilai Sig. 0,000. Nilai Sig. 0,000 tersebut lebih kecil dari 0,05 yang mengindikasikan bahwa $\mathrm{H}_{0}$ ditolak dan $\mathrm{H}_{1}$ dititerima. Dengan demikian manajemen strategis dan kompetensi kepala sekolah secara bersama-sama berpengaruh secara signifikan terhadap pencapaian standar pengelolaan pendidikan di SMA Negeri 19 Makassar. Besarnya pengaruh manajemen strategis dan kompetensi kepala sekolah secara bersamasama terhadap pencapaian standar pengelolaan pendidikan berdasarkan uji determinasi adalah 20,9\% dan 79,1\% ditentukan oleh faktor lain.

Hasil penelitian ini menunjukkan bahwa variabel manajemen strategis dan kompetensi kepala sekolah tersebut dapat memberikan kontribusi terhadap berbagai variabel lainnya, termasuk pencapaian standar pengelolaan pendidikan yang pada akhirnya berdampak pada pencapaian mutu pendidikan. Hal tersebut mengindikasikan pentingnya penerapan manajemen strategis dan kompetensi kepala sekolah yang efektif dalam pengelolaan pendidikan demi mencapai kualitas pendidikan yang diharapkan. Dengan demikian, semakin baik manajemen strategis dan kompetensi kepala sekolah yang diterapkan, semakin tinggi pula pencapaian standar pengelolaan pendidikan. Hasil penelitian ini telah membuktikan bahwa manajemen strategis dan kompetensi kepala sekolah di SMA Negeri 19 Makassar berpengaruh positif dan signifikan terhadap pencapaian standar pengelolaan pendidikan. Hal ini memberikan pemahaman bahwa manajemen strategis yang diterapkan dengan baik dan penerapan kepemimpinan oleh kepala sekolah yang 
efektif akan memberikan kontribusi terhadap pencapaian mutu pendidikan melalui pencapaian standar pengelolaan pendidikan. Oleh karena itu, pencapaian standar pengelolaan pendidikan di SMA Negeri 19 Makassar dipengaruhi oleh banyak faktor, diantaranya adalah manajemen strategis dan kepemimpinan yang diterapkan oleh kepala sekolah.

\section{PENUTUP/SIMPULAN}

Manajemen strategis di SMA Negeri 19 Makassar berada pada kategori baik, dengan persentase sebesar $77,21 \%$ yang menandakan bahwa penerapan manajemen strategis perlu dipertahankan dan ditingkatkan. Kompetensi kepala sekolah di SMA Negeri 19 Makassar berada pada kategori cukup, dengan persentase sebesar $65,53 \%$ yang menandakan bahwa kompetensi yang dimiliki oleh kepala sekolah masih perlu ditingkatkan. Pencapaian standar pengelolaan pendidikan di SMA Negeri 19 Makassar berada pada kategori baik, dengan persentase sebesar $81,45 \%$ yang menandakan bahwa standar pengelolaan pendidikan sudah dicapai dengan baik.Manajemen strategis berpengaruh positif dan signifikan terhadap pencapaian standar pengelolaan pendidikan di SMA Negeri 19 Makassar dengan persamaan regresi $Y=53,370+0,552$ dan nilai koefisien determinasi sebesar 0,146 sehingga pencapaian standar pengelolaan pendidikan $14,6 \%$ ditentukan oleh manajemen strategis.

Kompetensi kepala sekolah berpengaruh positif dan signifikan terhadap pencapaian standar pengelolaan pendidikan di SMA Negeri 19 Makassar dengan persamaan regresi $Y=78,720+0,277 X$ dan nilai koefisien determinasi sebesar 0,110 sehingga pencapaian standar pengelolaan pendidikan $11 \%$ ditentukan oleh kepemimpinan kepala sekolah.

Manajemen strategis dan kompetensi kepala sekolah secara bersama-sama berpengaruh positif dan signifikan terhadap pencapaian standar pengelolaan pendidikan di SMA Negeri 19 Makassar dengan persamaan regresi $Y=50,450+$ 0,467x1 $+0,216 x_{2}$ dan nilai koefisien determinansi sebesar 0,209 sehingga pencapaian standar pengelolaan pendidikan 20,9\% ditentukan oleh manajemen strategis secara bersama-sama dengan kepemimpinan kepala sekolah dan 79,1\% ditentukan oleh faktor lain yang tidak dalam wilayah penelitian ini.

Penelitian ini dapat memberi implikasi terhadap pemahaman para pengelola pendidikan, khususnya di sekolah tentang pentingnya penerapan manajemen strategis dalam pengelolaan pendidikan agar dapat meningkatkan pencapaian standar pengelolaan pendidikan yang pada akhirnya mengarah pada peningkatan mutu pendidikan di sekolah. Penelitian ini juga berimplikasi terhadap pemahaman kepala sekolah, khususnya kepala sekolah di SMA Negeri 19 Makassar tentang pentingnya kompetensi yang dimiliki kepala sekolah dalam melaksanakan tugas dan tanggung jawabnya agar tercipta iklim kerja yang kondusif sehingga membuat guru dan tenaga kependidikan merasa nyaman di sekolah dan meningkatkan motivasi mereka dalam melaksanakan tugasnya. 


\section{DAFTAR PUSTAKA}

Tiro, Muhammad Arif. (2008) Dasar-dasar Statistika. Cet. I; Makassar: Universitas Negeri Makassar

Afifah, Fatihatul. (2017) Kepemimpinan Kepala Madrasah dalam Meningkatkan Mutu Pendidikan di MI Negeri Model Slarang Kidul Lembaksiu Tegal, Laporan Penelitian. Purwokerto: IAIN Purwokerto.

Daryanto. (2011) KepalaS ekolah sebagai Pemimpin Pembelajaran. Yogyakarta: Gava Media.

Hunger, David J, dan Thomas L. Wheelen. (2003) Manajemen Strategis. Terj. Yulianto. Yogyakarta: Andi.

Pearce, John A. dan Richard B, Robinson Jr. (2013) Strtaegical Management: Formulasi Impelemntasid dan Pengendalian. Jakarta: Salemba empat

Machali, Imam, dan Ara Hidayat. (2016) The Handbiik of Education Management: Teori dan Praktik Pengelolaan Sekolah/ Madrasah di Indonesia.Jakarta:Prenada Media Group.

Manuling, M. (2006) Dasar-Dasar Manajemen. Yogyakarta: Gajah Mada University Press.

Mulyasa, E. (2010) Implementasi Kurikulum Tingkat Satuan Pendidikan. Jakarta: Bumi Aksara.

Republik Indonesia. (2015) Peraturan Pemerintah Republik Indonesia Nomor 13 Tahun 2015 tentang Standar Nasional Pendidikan. Jakarta: Sinar Grafika.

Sugiyono. (2014) Cara Mudah Menyusun Skripsi, Tesis dan Disertasi (STD). Bandung: Alfabeta.

Suryana, Asep dan Suryadi. (2009) Pengeloaan Pendidikan. Jakarta: Direktorat Jenderal Pendidikan Islam Departemen Agama RI.

Timor, Handriyani, dkk. (2018) Mutu Sekolah: Antara Kompetensi kepala sekolah dan Kinerja Guru, Jurnal Administrasi Pendidikan, XXV(12019). https://ejournal.upi.edu/index.php/JAPSPs/article/view/11568/6947 (02 Februari 2020).

Wahdjosumidjo. (2004) Kompetensi kepala sekolah: Tinjauan Teoritik dan Permasalahannya. Jakarta: PT. Raja Grafindo Persada.

Yusuf, Muri. (2014) Metode Penelitian: Kuantitatif, Kualitatif dan Penelitian Gabungan. Cet. I, Jakarta: Kencana. 